\title{
HYPOPARASITIC FUNGUS TUBERCULINA PERSICINA (DITM. EX FR.) SACC., AS BIOCONTROL AGENT FOR RUSTS
}

\author{
Shamim Shamsi* AND NAJMUn NAHER ${ }^{1}$ \\ Department of Botany, University of Dhaka, Dhaka-1000, Bangladesh
}

Key words: Tuberculina persicina, Hyperparasitic, Biocontrol agent, Rusts

The biological control of plant diseases has recently been gaining appreciable importance to plant pathologists. Intensive research has been done in this field to avoid the hazardous impact of pesticides and agro-chemicals on ecosystem. The biological agents, the mycoparasites have also attained a significant position. It has been suggested that efforts should be made to investigate the biological control of plant diseases through parasitism and predation. Tuberculina spp. are well-known mycoparasite and lot of research has been done on mycoparasitism of this fungus. Tuberculina persicina is contact parasite forming neither haustoria nor other intercelluler structures. However, at contact areas between $T$. persicina and its hosts, distinct interfungal interactions are observed. The host cells are dissolved at the point of contact.

Present study was made to evaluate the antagonistic efficiency and mycoparasitic activity of Tuberculina persicina (Ditm. ex Fr.) Sacc. against rust fungi Puccinia thawitesii Berk. on leaves of Justicia gendarussa L. and Uromyces appendiculatus (Pers.) Unger on Vigna sinensis L. In total ten samples were examined for each host. Freshly collected samples were used for microscopic observation of fungal structures. The samples were also placed in moist chamber following "Blotter method" for further investigations. Organisms from infected area were mounted on slides with lactophenol and cotton blue. Spore colour was examined on slides with water as mounting fluid. Digital and photomicrographs were made for each of the samples. Identification of the fungus was made following the relevant literatures. ${ }^{(1-2)}$ Samples were deposited in the Mycological Harberium of Botany Department, University of Dhaka, Bangladesh.

Specimen examined: 1. Puccina gendarussa (Acantheceae), Srimongal, Sylhat, S. Shamsi 2031 July 20, 2007. 2. Vigna sinensis L. (Leguminosae), S. Shamsi 2135, 24 January 2009, Botanical Research Garden, Curzon Hall Campus. 3. Vigna sinensis L. (Leguminosae), S. Shamsi 2149, 27 January 2009, Botanical Research Garden, Curzon Hall Campus. 4. Vigna sinensis L. (Leguminosae), S. Shamsi 2155, 11 February 2009.

*Corresponding author. ${ }^{1}$ Department of Botany, Life and Earth Science Group, National University, Gazipur-1704, Bangladesh, 
Tuberculina spp. are cosmopolitan and world-widely distributed, living in association with more than 150 rust species from at least 15 genera. Among 38 species, three species of Tuberculina are hypoparasites on rust fungi. These species are T. maximus, T. persicina and T. sbrozzii.(3) Other species of Tuberculina are reported as non pathogenic. After controversial discussions whether Tuberculina-like
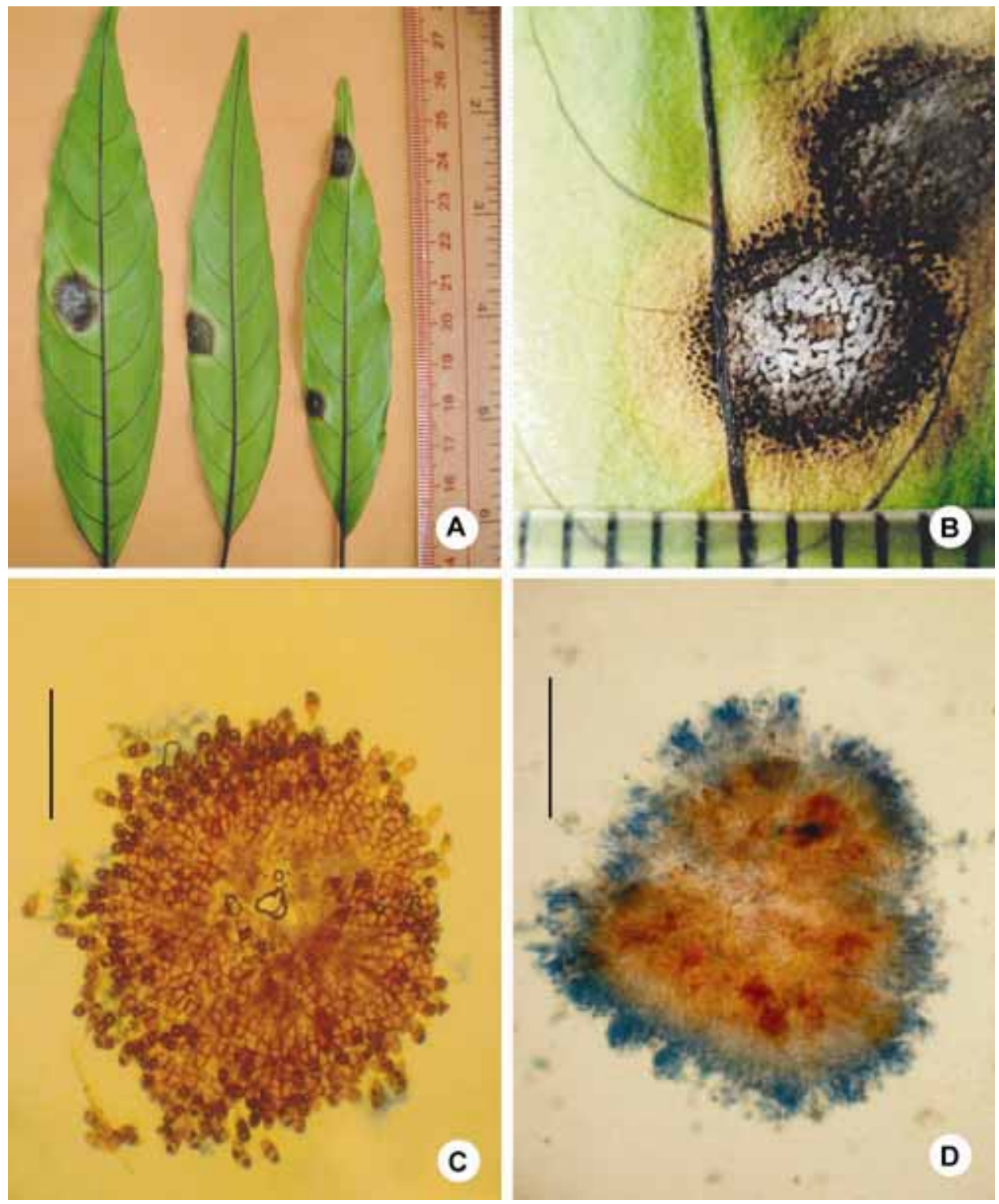

Fig. 1. A. Rusty pustules of Puccinia thwaitesii on Justicia gendorusa. B. Rust pustule surrounded by Tuberculina persicina. C. Teleospore of Puccinia thwaitesii and D. Teleospore of $P$. thwaitesii surrounded by Tuberculina persicina. $($ Bar $=50 \mu \mathrm{m})$. 

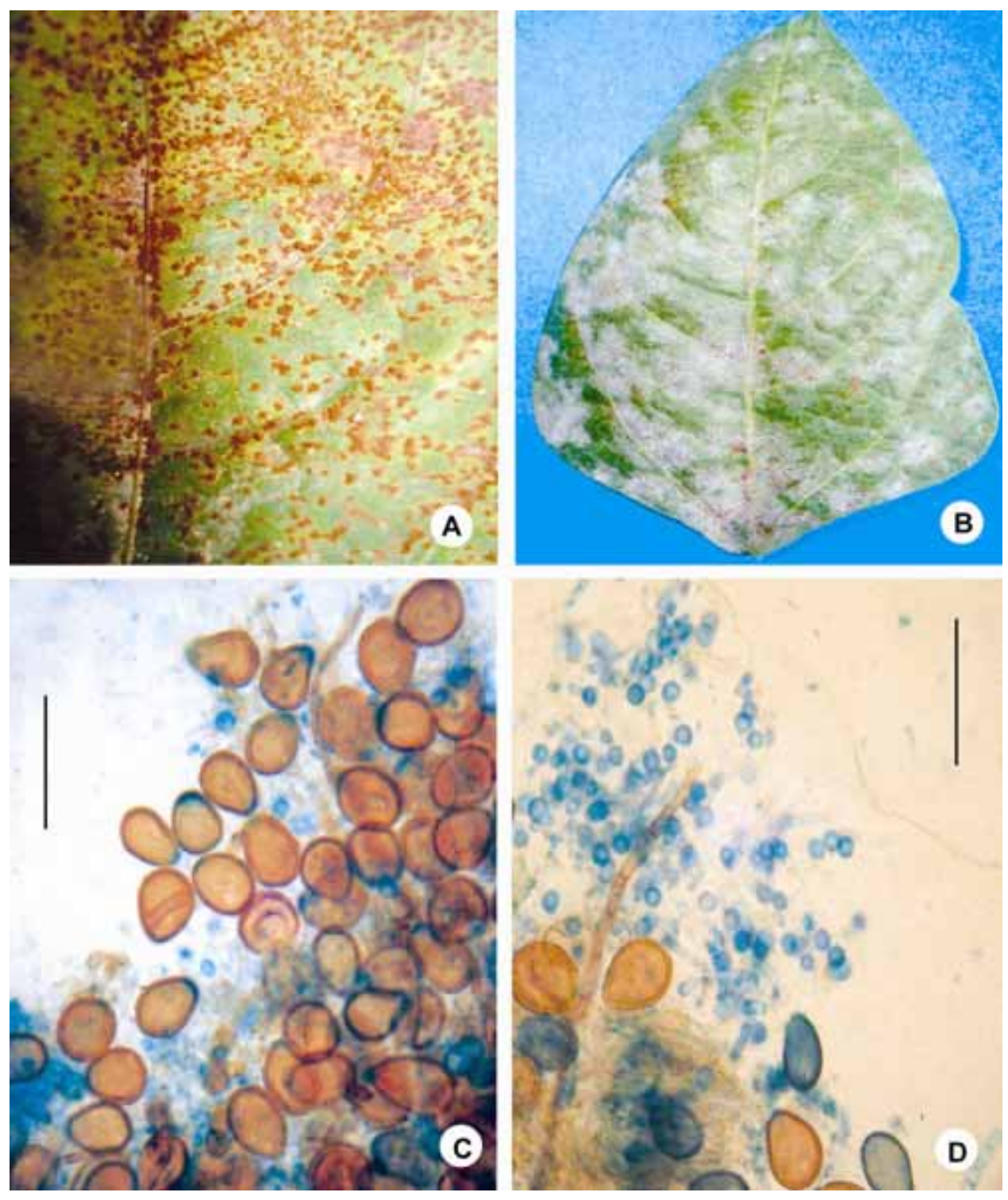

Fig. 2. A. Rusty pustules of Uromyces appendiculatus on Vigna sinensis. B. Rust pustules suppressed by Tuberculina persicina colonies. C. Urodeospore of $U$. appendiculatus and D. Urodeospores of $U$. appendiculatus suppressing by $T$. persicina . $($ Bar $=50 \mu \mathrm{m})$.

fungi should be treated as smuts, rusts, ascomycetes or hymenomycetes or hymenomycetes, the genus presently is assigned mostly to the fungi imperfect because no stages of sexual reproduction are known. Tuberculina are characterized by the formation of hemispherical lilac to violate sporodochia. They consist of palisade-like arrangement, short, moderately thick conidiogenous cells, each of which bears one globose, smooth conidium at the tip. The sporodochia break through the 
surface of higher plants and emit a powdery mass of the conidia. ${ }^{(4)}$ In addition, Tuberculina is known to exist only in association with rusts as first postulated by Saccardo. ${ }^{(5)}$ In Bangladesh $T$. percisina was found associated with rusty pustules of Puccinia thwaitessi Ber.(6)

In the present study $T$. persicina was found associated with teliosorus and teliospores and plant cells infected with rust fungi. The hyphae of $T$. persicina grew between teleosporse making contact with them and finally causing degradation of affected spores. The hyperparasite was occasionally seen to penetrate the plant tissue and appeared to cause rapid killing of plant cells infected with rust. The destruction of teliospore by $T$. persicina is probably the result of fungus enzymes action. At maturity pustules of $P$. thwaitessi were entirely surrounded by $T$. presicina. Teliospores of the rust fungi were completely destroyed by mycoparasite (Fig. 1A-D).

During the third weak of January 2009, leaflets of Vigna sinensis, were severely attacked by rust fungus Uromyces appendiculatus. The fungus is a biotrophic pathogen with an autoceous, macrocyclic life cycle. The most common symptom is small (up to $2 \mathrm{~mm}$ ) reddish-brown raised pustules (uredinia) on both surfaces of the leaf-lets. Numerous pustules covered the entire leaflets. The leaflets collapses turning yellow, drying out, and dropping prematurely. From 27 January, $2009 T$. persicina started to infect the leaflets and within seven days it destroyed uredeosorus of the rust fungi. Sporodochia of $T$. persicina was ruptured near the rust sorus and gradually destroy the uredosorus of $U$. appendiculatus. (Fig. 2A-D).

At late stage plants completely died. This investigation reveals that along with Trichoderma spp. and Trichotheceum roseum, Tuberculina spp. are playing significant role in nature as biocontrol agents. This study is an excellent examples of mycoparasitism.

\section{References}

1. Arthur JC 1928. Progress of rust studies. Phytopathology 18: 659-675.

2. Aurther JC 1934. Manual of the Rusts in united States and Canada. 1962 ed. Hafner, New York.

3. Ellis JP 1993. Description of some new species of fungi. Journal of Mycology 7: 274-278.

4. Lutz M, R Bauer, D Begerow and F Oberwinkler 2004. Tuberculina: rust relatives attack rusts. Mycologia 96(3): 614-626.

5. Saccardo PA 1882. Sylloge fungorum omnium hucusque congnitorum. Pavia, Italy 2(6): 1-38.

6. Khan AZM Nowsher Ali and H Jafar 1978. A note on the occurrence of six Hyphomycetous fungi on the rusty pustules of Puccinia thawitesii Berk. Bangladesh J. Bot. 7(1): 97-98. 
(Manuscript received on 26 July, 2009; revised on 30 September, 2009) 